\title{
Kujundsõnast eesti fraseoloogias
}

\author{
Asta Õim \\ Emakeele Seltsi tegevliige \\ asta.oim@gmail.com
}

\begin{abstract}
Teesid: Artiklis antakse ülevaade eesti fraseoloogia iseseisvatest süsteemsetest leksikaalsetest sisudominantidest ehk kujundi tekkes domineerivatest lekseemidest. Fookuses on sagedamate kujundsõnade eritlemise võimalikud teed ning keelelis-ontoloogiline analüüs esisaja eesti fraseologismi tähenduse aluseks olevate metafoorsete ülekannete allikmõistetest.
\end{abstract}

Märksõnad: eesti keel, fraseoloogia, kognitiivne lingvistika, kujundsõna, metafoor

\section{Sissejuhatuseks}

Fraseoloogiauurimise üks sõlmküsimusi näib peituvat mõisteliste ülekannete automaatses leidmises kontekstist. See eeldab erinevaid eeltöid, mille hulka kuulub eeskätt fraseologismide leksikaalse koosseisu, sh kujundidominandi väljaselgitamine.

Viimastel aastatel on Eestis korrastatud ja uuritud põhiliselt arhiivifraseoloogiat. Arvukatele tüpoloogilistele, leksikograafilistele ja korpuslingvistilistele küsimustele leitakse järjest sagedamini vastuseid kognitiivses paradigmas, mille järgi inimlik mõistesüsteem on struktureeritud ja määratletud suuresti metafoorselt, järelikult on metafoorselt struktureeritud ka mõistetele vastavad tegevused ja keeleüksused (vt nt Lakoff \& Johnson 2003: 3; Lakoff 2006: 186; Gibbs 2002: 262). Seejuures ei pea verbaalsed metafoorid olema alati konventsionaalsed - nii nende mõistemustreid kui ka uudset metafoorset keelt motiveerivad ühed ja samad argitunnetuses olulised metafoorsed teadmised põhimõistetest. Need teadmised mõjutavad idioomide ${ }^{1}$ keelelist käitumist, ajendavad meid kasutama ja mõistma mitteidiomaatilisi väljendeid, uudseid verbaalseid metafoore. Sellepärast ei ole õige käsitleda paljusid kõnes ette tulevaid väljendeid kuidagi teisiti - nad kõik peegeldavad keelelisi ja mõistelisi 
teadmisi, mida kasutatakse igapäevastest kogemustest rääkides. (Gibbs 2002: $262 \mathrm{jj}, 318$.

\section{Empiiriline materjal}

Uurimismaterjal pärineb Eesti Kirjandusmuuseumi Eesti Rahvaluule Arhiivi kõnekäändude kartoteegi tüpoloogilise ja mõistelise töötlemise tulemusena koostatud "Eesti fraseologismide elektroonilisest alussõnastikust". Nimetatud kartoteegi keelematerjal on valdavas osas üles kirjutatud keelejuhtide suulisest kõnest mitte spetsiaalselt, vaid rahvaluule ja murdekeele kogumise kõrvalt (vt ka Krikmann 1999), ning on pärit põhiliselt 20. sajandi esimesest poolest. Vanimad üleskirjutused kartoteegis on 19. sajandi algusest, uusimad 20. sajandi lõpust. Võib öelda, et see suhteliselt sihipäratult kujunenud keelekogum annab 150 aasta lõikes teatava pildi mitte niivõrd eesti fraseoloogiast, kui just sellisest keelekasutusest, mida keelejuhid jt on intuitiivselt pidanud metafoorseks (põhjalikumalt Õim, K. \& Õim, A. 2011). Siiski on selle kartoteegi alusel valminud "Eesti kõnekäändude ja fraseologismide andmebaas" (EKFA), "Eesti kõnekäändude ja fraseologismide mõistestik" (Õim, A. 2008) ning eespool mainitud "Eesti fraseologismide elektrooniline alussõnastik" (FES), mis aitavad empiirilises materjalis orienteeruda ja hõlbustavad selle uurimist mitmest aspektist.

EKFA on tüpoloogilise ülesehitusega kõnekäändude ja fraseologismide leksikaalsemantiline andmebaas, mis sisaldab digitaalsel kujul u 160000 kõnekäänuteksti koos arhiiviviite ja -andmetega tekstide kogumiskoha, kogumisaja, koguja ja keelejuhi kohta. Et materjalile paremini ligi pääseda, lemmatiseeriti väljendid ning loodi kõnekäändude ja fraseologismide mõistestik, mis sisaldab 998 ülemtasandi mõistet (Õim, A. 2008). Mõistetena on käsitletud teadmiste põhiüksusi, mis on kategoriseerimises ja mõistestuses (tähenduse konstrueerimises) kesksel kohal. Materjal on märgendatud mõistetasandil vastavalt tähendusele.

Paraku ei andnud kõnekäänukartoteegi korrastamiseks valitud folkloristlik tüpoloogiline lähenemine rahuldavaid tulemusi (vt lähemalt Õim, K. 2005), mis tõi kaasa vajaduse tüpoloogia ja fraseologismilemmade parandamise järele. Nii valmiski 2011. aastal tesauruselaadne FES, mis toetub nimetatud kahele veebirakendusele, kuid on suuresti konkretiseeritud: EKFA rohkem kui 35000 väljendi asemel on FES-is 20749 fraseologismi, mis on analüüsitud kognitiivse keeleteaduse põhimõtetel ja koondatud mõisteseoste järgi. Selles mõistelises ainekogumis 1) eksplitseeritakse fraseologismide tähendusi motiveerivate mõistemetafooride sihtvaldkonnad, 2) käsitletakse fraseologisme süntakti- 
liste üksustena ning 3) eksplitseeritakse fraseologismide morfosüntaktiline struktuur. Et siduda üksteisega haakuvad mõisted, on rajatud mõisteülene süsteem: mõisted on jagatud ja märgendatud vastavate üldmõistete järgi, viimased omakorda mõisteklasside ja mõistekategooriate järgi. Kasutajaliides võimaldab lisaks andmete lihtotsingule leida väljendeid mõistelise kuuluvuse ja funktsiooni järgi ning annab sedakaudu ka teatava ülevaate eesti vanemate väljendite tähendustest, semantilistest seostest, süntaktilistest mallidest, leksikaalsetest jt üldisematest tunnustest. Sõnastikus antav eesti fraseologismide terviklik semantiline, süntaktiline ja morfoloogiline kirjeldus võib olla lähtealuseks järgnevatele eesti fraseoloogiat käsitlevatele uurimustele. Märkigem, et FES-ist on fraseologisme lihtne leida ka siis, kui kasutaja ei tea, millist konkreetset sõnaühendit või selle vormi otsida, kuid suudab otsitavat seostada näiteks mõne ontoloogilise mõistekategooriaga (vt ka Espinal 2005: 513 jj).

\section{Fraseologismi idiomaatiline kese}

Fraseologismi käsitatakse FES-is ja ka käesolevas artiklis kui konventsionaalset keeleüksust, mille mõistmiseks ei piisa ainult keele grammatikareeglite ja sõnavara tundmisest (vt nt Baranov \& Dobrovolski 1991: 7, 2005: 8; Evans 2007: 105). Ehk teisisõnu: fraseologism on selline keeleüksus, millel on oma tähendussisu, vorm ja kujundituum. Viimast on nimetatud ka keskseks pildielemendiks, kujundlikuks sisuelemendiks, tuumelemendiks, sisudominandiks, idiomaatiliseks keskmeks, kujundsõnaks. Soome folklorist Matti Kuusi (1963: 340) on üle poole sajandi tagasi kasutanud terminit ydin, mis iseloomustab seda nähtust ehk kõige paremini.

Fraseologismi kujundituum võib olla leksikaalselt erinevalt vormistatud: alates ühest sõnakujust (nt lihtvõrdlustes kui karu) kuni mõistekompleksini lausekujulistes väljendites (nt Oleks onul küüned, roniks puu otsa). Et väljendist üles leida selle kujundlik sisudominant, tuleb lähtuda kujundi tekkemehhanismist ning arvestada, milliste semantiliste muutuste käigus ja tulemusena see on tekkinud ning millised formaalsed leksikaalsed ja grammatilised muutused leiavad aset väljendi aktualiseerumisel.

\section{Fraseologismi tekkemehhanismid}

Inimkeel on tõenäoliselt loonud esmalt leksikaalsed vahendid reaalse füüsilise ehk materiaalse maailma objektide ja suhete tähistamiseks. Abstraktsete objektide ja vahekordade ning inimese mentaalsete omaduste, tajude, seisundite, 
toimingute jms edastamise tähiseks on laenatud leksikaalseid vahendeid juba olemasolevate, füüsilist maailma refereerivate hulgast, olles neid pigem ümber mõtestanud kui et selleks spetsiaalselt erisõnavara loonud. Kujundsõna eristamise eesmärk seisnebki selles, et tuvastada need reaalse maailma objektid, mis osalevad mentaalsete omaduste tähistamises, ja selle kaudu jõuda mõistevaldkondadeni, mis omavahel suhestuvad. Allpool peatun ümbermõtestamise olemusel ja kõige olulisematel semantilise teisenemise juhtudel.

\section{Ümbermõtestamine ehk semantiline teisenemine}

Ümbermõtestamine ehk semantiline teisenemine on operatsioon, mille käigus ühte mõistealasse kuuluv(ad) tähendus(ed) projitseeritakse teisele, tulemuseks on transformatsioon - A on B mingi toimingu alusel (Baranov \& Dobrovolski 1996: 53 jj, 2008: 33-46). Vaatame seda sõna nina näitel.

(1) Ta nuuskas nina.

(2) Ta seisis laeva ninas.

(3) Ta hõorrus salvi nina alla ohatisele.

(4) Ta hõõrus mulle viltulaskmist nina alla.

Lausetes (1) ja (3) on nina kasutatud otsetähenduses, tähendus A 'inimese hingamisteede algusosa' on ka lauses sama, seega A on A. Lauses (2) on nina kasutatud ülekantud tähenduses, tähendus A on lauses kasutatud tähenduses B 'mingi asja, antud juhul laeva eenduv ots' ning tegemist on ümbermõtestamisega lekseemi tasandil, seega A on B. Lauses (4) on ümber mõtestatud lisaks ninale ka verb hõoruma ning tulemuseks on uus, teise mõistevaldkonda kuuluv tähendus 'kellelegi ühte ja sama ette heitma'. Projektsioonitehteks R on nii (2) kui ka (4) puhul metafooril baseeruv ülekanne.

1. Terviku ümbermõtestamise käigus hakatakse otsetähenduses lekseeme kasutama muutmata kujul metafoorselt: väljend A, millel on situatsioonis A tähendus A, mõtestatakse situatsioonis B ümber tähenduses B (Baranov \& Dobrovolski 2008: 33-34). Näiteks väljenditele Ameerikat avastama, naelapead tabama, omil jalul seisma, karvu pihku võtma, juukseid katkuma, härjal sarvist haarama, siga ka ei söö on ühine see, et nad on kasutatavad vastavates situatsioonides niisuguses tähenduses, mis tuleneb nimetatud sõnaühendite komponentide tähendustest. Ümbermõtestatuna teistes situatsioonides tähendavad nad hoopis midagi uut, vastavalt tähendustes 'midagi ammutuntut uue pähe välja pakkuma', 'täpselt toimima', 'majanduslikult ise toime tulema', 
'karistama', 'meeleheitel olema', 'otsustavalt tegutsema hakkama' ja 'täiesti kõlbmatu olema'. Seega ei iseloomusta idiomaatilisus üksnes fraseoloogiat, vaid ka teisi loomulikku keelekasutusse kuuluvaid keelendeid. Kui samasugune semantiline teisenemise leiab aset lekseemi tasandil, siis tekib metafoorse või metonüümilise ülekande tulemusena polüseemne lekseem, nt lammas 1. sõraline villkattega koduloom, 2. lambaliha (hautatud lammas), 3. lambanahk (Ungari lambast kasukas) või 4. alistuv ning arg inimene, tossike (Ta pole mees, ta on lammas).

2. Intensionaalne ümbermõtestamine erineb terviku ümbermõtestamisest selle poolest, et algsel sõnaühendil puudub tõeväärtus ehk tõele vastav situatsioon (Baranov \& Dobrovolski 2008: 34). Üpris raske on ette kujutada olukordi, mida iseloomustaksid otseses tähenduses veresaun, jalgu selga võtma, torm veeklaasis, sääsest elevanti tegema.

3. Komponendikeskne ümbermõtestamine leiab aset juhtudel, kui sõnaühendis teiseneb semantiliselt iga komponent eraldi ning väljendi tähendus formuleerub koostisosade ümbermõtestatud tähendustest (Baranov \& Dobrovolski 2008: 35). Näiteks väljend ussike põrmus, millel puudub korrelaat otsese tähendusega, on tekkinud koostisosade uss 'loogeldes liikuv pikliku kehaga selgrootu' ja põrm 'muld, maapind, tolm' ümbermõtestamise tulemusena, kusjuures mõlemad komponendid osutavad metafoorselt inimese madalale sotsiaalsele staatusele: ussike 'haletsusväärne, tähtsusetu inimene', mida võimendab deminutiivliide -ke, ning põrmus 'madalas, alandatud olekus'. Vrd veel: siidis ja sametis käima elama (siidis, sametis 'kvaliteetne hinnaline kangas' => jõukas elu), kärina ja mürinaga 'hoogsalt, intensiivselt' (kärin, mürin 'hoogsa tegevusega kaasnev heli' => kiirus). Selline idioomi tekkemehhanism ei eelda tervikkeelendi metafoorset ümbermõtestamist, vaid väljend pannakse kokku ümbermõtestatud komponentidest ükshaaval.

4. Terviku ositise ümbermõtestamise korral ei mõtestata ümber kõiki väljendi tähendust kandvaid komponete, vaid üksnes osa neist (Baranov \& Dobrovolski 2008: 44-45). Mõnikord säilitavad oma esialgse otsese tähenduse isegi mitu semantiliselt olulist osist: kõvera kase kaudu sugulane 'kauge sugulane', valetab nii et suu suitseb 'palju valetama', oma peaga vastutama 'oma eluga garanteerima, vastutama', silmi peast nutma 'palju nutma', raha sügeleb taskus 'keegi tahab raha kulutada', sööb nagu lind 'sööb väga vähe', laulab nagu linnuke 'laulab hästi; räägib ladusalt'. Harald Burger (2010: 40) nimetab selliseid väljendeid osaidioomideks (sks k Teil-Idiome). Fraseologismide areng näitab, et diakroonilisest aspektist võib ka mõistemetafoori kasutamata osade rakendamine päädida metafoorsete lekseemide leksikaalse teisenemisega, vrd järgmisi näiteid FES-ist: kui oks tuule käes 'ilma kaitseta, hoolitsuseta, näi- 
teks vaeslaps', kui leht tuule käes 'ebapüsiv, ebakindel, näiteks sõprus' ja kui puu tormi käes 'kahtlev, otsustusvõimetu'; käed on kinni 'saamatu, aeglane', 'hõivatud', käed on kõhus kinni 'saamatu, aeglane' ja käed on süles kinni 'naine väikese lapsega hõivatud', käed külmad tähenduses 'surnud' ja käed külmad kui surnul 'külmad käed'.

5. Grammatiliste omaduste teisenemisel muudab väljendi sisu kandev komponent oma kategoriaalset kuuluvust (vt Korhonen 2002: 402; Baranov \& Dobrovolski 2008: 38). Näiteks väljendis ehku peale täidab sidesõnast komponent ehk substantiivi rolli ning saab nimisõna omadused: 1) ei vormista lausesisest rinnastust nagu ehk-sidesõnale kohane, vaid täidab väljendi struktuuris moodustaja rolli, 2) käändub (esineb ainsuse genitiivi vormis) ja 3) omab leksikaalset tähendust 'ebakindel olek, ebakindlus'. Lauses talitleb väljend ehku peale määrusena ning on ilmselt aja küsimus, mil need kaks sõna sulavad kokku liitmäärsõnaks ehkupeale.

Nimisõna funktsioone täidavad väljendeis lisaks sidesõnadele (agal on saba taga) ka pronoomenid (ah sa mu meie, kus sa sellega, sina peal) ning teistessegi mittetäistähenduslikesse muutumatutesse sõnaliikidesse kuuluvad sõnad, nagu aitäh eest, ei ütle ei ega jah, mitte üks noh.

6. Näiv ammendatus on üks idiomaatilisuse kodeerimise viise, milles loetletakse üles mingi hulga mõned elemendid, mis ei hõlma koguhulka, kuid mida interpreteeritakse nii nagu nad teeksid seda (Baranov \& Dobrovolski 2008: 40-41). Tavaliselt märgivad sellise väljendi elemendid millegi piirmäära. Näiteks ei lausu musta ega valget ei tähenda 'ei ütle musta' ja 'ei ütle valget', vaid 'ei ütle seda, mis algab mustaga, hõlmab kõiki vahetoone ja lõpeb valgega' ehk teisisõnu 'ei ütle mitte midagi, vaikib'. Eesti keeles on mitu vaegelementidega järjestatud hulga konstruktsiooni:

6.1. ei X ega $Y$, mille korral X ja Y tähistavad sageli piirelemente, nt ei anna kuiva ega märga, ei ole otsa ega äärt. Hulka ja määra märkivate elementide valikut võib eesti keeles tõenäoliste objektide kõrval sagedasti dikteerida üksnes nende häälikuline kooskõla, riim ja rütm. Näiteks ei ole pala ega pauku ei hõlma potentsiaalseid omamisobjekte, ometi me mõistame seda väljendit just kõike hõlmavana. Konstruktsioon ei $X$ ega $Y$ on eesti fraseoloogias väga produktiivne: ei kihku ega kahku, ei kippu ega kõppu, ei ole rege ega ratast, ei pääse läbi hiir ega harakas, ei keetu ega kannikat, ei saanud suhu ega silma, ei ole kotis ega sopis, ei ole tegijat ega olijat.

6.2. Konstruktsioon $X$ ja Y : risti ja põigiti, risti ja rästi 'igati, kõigiti' (otsus oli risti ja rästi läbi kaalutud), kopsud ja maksad 'kõik siseelundid', luku ja riivi taga, liha ja veri, lihast ja luust, teeb uut ja vana. 
6.3. Järjend ei ole ammendav ka konstruktsioonis $X v \tilde{i} i Y$, kus või vormistab ühendavat rinnastust: võta või jäta / võtta või jätta (koer oli võta või jäta hunt), nuta või naera, võta heaks või pane pahaks, ees või taga, surm siin või Siberis.

6.4. Näivale ehk pseudoammendatusele on lähedased ka konstruktsioonid iga-komponendiga, kus iga otseseid tähendusi 'ükskõik milline üksik paljude omataoliste hulgast' ja 'igasugune, ükskõik missugune paljude erinevate hulgast' interpreteeritakse ammendatusena: iga hinna eest, iga juuksekarva otsas tilk 'üleni tugevasti higine', iga ihukarvaga 'kogu oma olemusega', iga kandi pealt (seda asja kaaluti iga kandi pealt), logiseb igast tapist, igas tükis (igas tükis parem).

7. Tsitaadi (sh vanasõna) teisenemine. Nagu eespool märgitud, võivad üht ja sama kujundimehhanismi järgivad keelendid leksikaliseeruda erineval moel - polüseemse lekseemina, fraseologismina, vanasõnana. Kõigil juhtudel, kui mingi väljend on moodustatud teise baasil, viitab selle tähendus mingil viisil lähteväljendi semantikale (vt Baranov \& Dobrovolski 2008: 39-40). Siia kuuluvad näiteks autoritsitaadid ja vanasõnade baasil tekkinud fraseologismid: Ega inimene varnast võtta ole (EV 2090), Egas mägi varnast võtta pole (EV 7066) ja varnast võtta olema. Vanasõna ja fraseologismi ilmseim erinevus on selles, et vanasõnal on üldjuhul didaktiline, fraseologismil tähistav ülesanne (vt Krikmann 1997: 52 jj).

Fraseologismid on vanasõnadega võrreldes oma suhteliselt mitmekesisema ja vabama varieerumise tõttu kasutuses tavalisemad ja elujõulisemad. Nagu näitab FES-i materjal, saavad vanasõnade fragmentidest tihiti iseseisvad idiomaatilised keelendid. Näiteks tuntud vanasõna esimene vasikas läheb aia taha (EV 698) on taandunud idioomiks aia taha minema, mille tekkeprotsessi võib kujutleda kaheetapilisena. Esimesel etapil leiab aset otsese tähendusega väljendi didaktiline üldistamine - 'sellel, kes proovib midagi teha, ei pruugi see esimesel katsel õnnestuda' - ning tulemuseks on vanasõna tähenduses 'esimene katse ebaõnnestub'. Teisel etapil on reduktsiooni käigus kahanenud väljendi vorm ja avardunud sisu ning selle tulemuseks on idioom aia taha minema, millel on suhteliselt lai ja üldine tähendus 'ebaõnnestuma'.

Autoritsitaatide ümbermõtestamisega on tegemist meile hästi tuttavate näidetega. Juhan Liivi jutustuses "Peipsi peal" hüüab uppumisest pääsenu: "Jaak, maa, kurat, jalad on juba põhjas!" Semantiliselt ümbermõtestatuna tunneme selle baasil tekkinud väljendit jalad on põhjas üldistatud tähenduses 'suur hädaoht on möödas'. Oskar Lutsu "Kevade" järgi tuntuks saanud Kui Arno isaga koolimajja jõudis, olid tunnid juba alanud on läbi teinud sedavõrd palju leksikaalseid modifikatsioone, et selle aktualisatsioonid oleks õigem üldistada süntaktiliseks malliks kui $N X$-sse jõudis, oli $Y$ juba alanud. Algne tähendus 
'Arno jäi kooli hiljaks' on teisenenud tähenduseks 'keegi on millegi alustamisel, millelegi jaole jõudmisel hilinenud, teistest maha jäänud', nt Kui väike kalamees [..] isaga koos kalale jõudis, oli masu juba alanud ${ }^{2}$; Kui vahetusüliõpilane koju tagasi jõudis, oli eesti rahvas juba välja surnud ${ }^{3}$. Või tuntud laulust pärit jätke võtmed väljapoole, mille algne tähendus sisaldas üleskutset igal ajal sõpru võõrustada, on teisendunud humoorikaks hoiatuseks halbade kavatsustega sissetungijate vastu: Jutt võtmete väljapoole jätmisest varga tarbeks on muidugi liialdus, küll aga ei maksaks ${ }^{4}$.

\section{Fraseologismide tuumelemendi ehk kujundsõna formaalne}

\section{teisenemine}

Kui otsetähenduses lekseemid saavad metafoorse tähenduse, ilma et nende endiga mingeid muutusi toimuks, siis metafoorsed lekseemid võivad teiseneda nii leksikaalselt (nt asenduvad fraasi osised) kui ka süntaktiliselt (nt muutub keelendi sõnaliik või süntaktiline funktsioon).

Fraseologismide seas ei ole kuigi palju muutumatuid ehk klišeelisi idiomaatilisi keelendeid (nt nagu Jeeriku pasun). Enamasti leiab neis aset mingi leksikaalne või grammatiline muutus. See on loomulik ja seletatav loova kognitiivse protsessina: keeleline loovus tuleneb meie kommunikatiivsest eesmärgist kohandada keeleüksused (kognitiivses grammatikas - juurdunud vahendid) keerukate ja pidevalt muutuvate mõistestamiste kodeerimiseks kontekstuaalselt sobivalt (Langlotz 2006: 175, 188). Kõiki fraseologismi tekstilise kasutuse juhtumeid ei ole sugugi alati õige pidada leksikaliseerunuks. FES-is demonstreerivad seda üleskirjutused, mis pärinevad eri murdealadelt ja on suure ajalise distantsiga. Fraseologismide teisendid näitavad neid grammatilisi ja leksikaalseid mooduseid, kuidas üht või teist kujundit on eri murretes pika aja vältel kasutatud.

Kujundsõna formaalses teisenemises eristab Andreas Langlotz tavalist, juhuslikku ja pseudoteisenemist (Langlotz 2006: 215, 216). Tavalise formaalse muutuse tulemusena tekivad 1) institutsionaliseerunud formaalsed teisendid, nagu ei ole saba ega sarvi > saba ega sõrga hända ei sarve hända ega otsa saba ega hända suud ega saba, või institutsionaliseerunud polüseemia, nagu käed lööma 1. 'kihla vedama' > 2. 'kokku leppima'; 2) süsteemsed teisendid, nagu mantlit pärima > mantlipärija, mantlipärimine, auku kaevama > augukaevaja; surm otsib laternatulega taga > otsib surma laternatulega taga.

Fraseologismide tavalised teisendid on loodud kontekstist sõltuva diskursiivse kavatsuseta. Nad on korduvad ja institutsionaliseeritud ning võivad seega olla leksikograafiliselt fikseeritud. Süsteemsetel teisenditel säilib nende 
regulaarne morfosüntaktiline ja süntaktiline variaablus. Tavalised teisendid kattuvad osaliselt juhuslikega, mille hulka kuuluvad mh süsteemsed kodeeritud kõrvalekalded idioomi põhivormist. Juhusliku teisenemise tulemusena sünnivad kas 1) süsteemsed juhuslikud teisendid, nt paneb põhja peale $>$ pane põhi püsti viska põhi peale Põhi peale! Põhi välja!, 2) taotluslikud, teadlikud sõnamängud, nt augutäide > auk ei tohi tühi olla või, 3) kogemata tekkinud valeteisendid ja keelevääratused, nt (naerab) nii et vats vabiseb > (naerab) et kõht loksub.

Juhuslikud teisendid luuakse diskursiivsetel eesmärkidel ühe kindla kasutussündmuse käigus. Need on ajutised, neid piirab kontekst ja kotekst, milles nad esinevad. Seetõttu ei saa juhuslikke teisendeid fikseerida, samuti ei saa nad kognitiivselt juurduda. Fraseologismide juhuslikud teisendid hõlmavad ka sõnamänge (Langlotz 2006: 177, 199). Sõnamänguga on tegu näiteks siis, kui fraseologismi kasutatakse meelega mitmetähenduslikult või kui fraseologismi kasutamisel tekib vastuolu selle konventsionaalse idiomaatilise tähendusega. Keelevääratused on ajutiste kõrvalekalletena ebaolulised (Langlotz 2006: 201). Oluline on, et mistahes uudne idiomaatiline konstruktsioon oleks kommunikatiivselt toimiv ja niivõrd konventsionaalne, et kuulaja suudaks selle kontekstile viitamise ja oma mälus salvestatud lingvistiliste skeemide abil ära tunda ja dekodeerida. Seega on idioomide muutmine kasutuskeskne.

Fraseologismide pseudoteisendid on tõlgendatavad ainult sõna-sõnalt, nad ei aktiveeri idiomaatilist tähendust ega ole kasutuskontekstis äratuntavad, nt teravad kü̈̈ned > (ära arva, et minu) kü̈̈ned on nürid (Langlotz 2006: 177, 224).

\section{Mõiste abil kujundsõnani}

Mõisted kuuluvad struktureeritud ja korrastatud mõistesüsteemi ning võivad olla kodeeritud keelespetsiifiliselt, s.t leksikaalsete mõistetena. Kuigi tegu on suhteliselt püsivate kognitiivsete olemitega, muudavad neid jätkuvad, samas juhuslikud ja korduvad kogemused (Evans 2007: 31, 38). Tähenduse konstrueerimine toimub mõistetasandil: selle käigus ajendavad sõnad jm keeleüksused mõisteliste operatsioonide organiseerimist ning taustteadmiste rakendamist. Seega on tähendus pigem protsess kui miski, mida keel "pakendab" (Evans 2007: 131).

Metafoorsed keelendid kasutavad suure tõenäosusega meie metafoorselt liigendatud mõistete süsteemi, rajanevad sellel ja esinevad harva sellest sõltumatult (Lakoff 2006: 213). Argitunnetuses olulised metafoorsed teadmised põhimõistetest ajendavad meid sama hästi kasutama ning mõistma idiomaatilisi, mitteidiomaatilisi ja ka uudseid metafoorseid keelendeid (vt Gibbs 2002: 318). 
Stabiilne vastavus mõistealade mõistete vahel tagab metafooride mõistmise kõrval ka nende leksikaliseerumise ja leviku, mis omakorda kinnitab püsikindla ülekande olemasolu (vt Lakoff \& Johnson 1999: 149). Sama skeem rakendub vanema keele metafooride mõistmisel sünkroonsel tasandil.

FES-i üks eesmärke oli sihtmõistete formaliseerimine. Semantiliselt analüüsiti 20749 fraseologismi, mille tulemuseks saadi keelelis-ontoloogiline ülevaade fraseologismide tähenduse aluseks olevate metafoorsete ülekannete sihtmõistetest. Makrotasandil ongi FES-i põhiüksusteks 1893 mõisteartiklit, mille keskmes on vastava sihtmõistega semantiliselt või kognitiivselt seotud ja seega suhteliselt lähedase tähendusega fraseologismid. Polüseemsed või homonüümsed fraseologismid kuuluvad mitmesse mõisteartiklisse (neid on 6064). Seega koondab FES 26813 tähendusüksust, mis on mõisteartiklites järjestatud morfosüntaktilise struktuuri järgi. Metafoori allikmõisteid analüüs ei hõlmanud, mistõttu fraseologismide mõistelist motivatsiooni ei ole FES-is eksplitseeritud.

Allikmõisteni jõudmiseks tuleb kõigepealt kindlaks teha väljendi lähtealus, s.t reaalse maailma objekt. Näib, et selle leidmiseks on otstarbekas lähtuda sihtmõistest. FES-is on kasutusel hierarhiliselt jagunev mõisteülene süsteem: mõistekategooria > mõisteklass > üldmõiste > mõiste ning kogu materjal on sellekohaselt märgendatud. Eesmärk on siduda üksteisega erinevaid mõisteid (nt SUGULASED ja LAPSED; VANADUS ja SURM) ning välja tuua paradigmaatilised mõisteseosed. Mõistehierarhia madalaima taseme üksusi käsitatakse FES-is kui metafoori sihtmõisteid, mis motiveerivad koos allikmõistetega enamiku fraseologismide tähendusi (mõistelise allik- ja sihtvaldkonna eksplitseerimise olulisusest fraseologismide mõistelisel organiseerimisel vt Õim, K. 2009). Eeldatakse, et sõnastikukasutaja teadmised fraseologismist sõltuvad suuresti tema võimest tajuda mõistelisi seoseid (vt Espinal 2005: 513, 523), et mõisteline esitus suunab suurema tõenäosusega fraseologismide konkreetse valikuni (vt Kövecses 2000: 3 jj). Kuna selline mõistesüsteem viib kokku samal ontoloogilisel ülekandel põhinevad semantiliselt seotud ehk sama üldise ja denotatiivse tähendusega väljendid, siis see mitte üksnes ei kajasta fraseologismide tähenduse arenemisjärke, teisenemist ja funktsioonimuutusi, vaid hõlbustab ka allikmõistet katva leksikaalse materjali väljaselgitamist. Näiteks mõiste rumalus koondab väljendid, milles on hõlpus eristada loomkujundeid: nagu lammas, nagu lakkumata vasikas, nagu vana kass ahju peal. Mõiste erinev alla kuuluvad samas või sarnases tähenduses fraseologismid, millest paljudel on sama või sarnane ehitus ning mille lähtealaks on aine, asi, loom, kehaosa või astronoomiline mõiste: teisest puust, teisest savist, teist nahka, teisel karval, kui valge vares, justkui saarlase saapatikud, kui tuli ja vesi, nagu maa ja taevas, nagu siga ja hani, nagu siga ja kägu, nagu öö ja päev jne. Mõiste jäik 
'paindumatu' baseerub kõvade asjade omadustel: kont kõhus, kange kui pulk, nagu kü̈̈̈narpuu alla neelanud, nagu nui, nagu puupakk, nagu puukaru, nagu puuhobune, nagu puujalge peal jpt.

\section{Eesti fraseologismide kujundsõna sagedus ja ontoloogiline iseloomustus}

\section{Kujundsõnade sagedusest}

Temaatika poolest peegeldub fraseoloogias antropotsentristlik maailmanägemine - fraseoloogia huvifookuses on inimene ja inimestevahelised suhted, nii sotsiaalsed kui ka majanduslikud. Märksa vähem on neid väljendeid, mis peegeldavad arusaamu maailma asjadest.

FES-i jaoks välja töötatud ühtse keelelis-ontoloogilise mõistehierarhia järgi (Õim, K. \& Õim, A. 2011: 849) kuulub mõistekategooriate hulgas ettearvatult enim materjali kategooriasse inimene (77,9\%), järgnevad KVALiteET (10,5\%), MAAILM JA LOODUS (1,99\%), HULK JA MÄÄR (1,61\%), AEG (1,53\%) ning ÜLELOOMULIKUD NÄHTUSED $(0,24 \%)$. Kategooriate hulgas erandlikku FUNKTSIONAALSETE VÄLJENDITE $(6,17 \%)^{5}$ rühma on arvatud muudest fraseologismidest täpsema ja piiratud pragmaatilise orientatsiooniga viisakusväljendid (nt ole meheks; võta heaks), hüüatused ja hüüded (nt oh sa sula; oh mina vaene mehike, kaks jalga, kolmas lühike), sõimusõnad (nt vana hapukäkk), kiirkõned (nt kuuratsanikud kuuvalgel ö̈l) jms.

INIMESE kategooria hõlmab omakorda suurima hulga mõisteklasse. Kõige rohkem fraseologisme, kuulub selles kategoorias ülekaalukalt mõisteklassi INIMENE KUI TERVIK, järgnevad klassid INIMESTEVAHELISED SUHTED; TÖÖD JA TEGEMISED, ELATUSALLIKAD; OMAND JA OMANDISUHTED; HALB JA HEA ELU; KODU JA MAJAPIDAMINE, RÕIVAD; ÜHISELU KORRALDAMINE ning ABIELU, PEREKOND JA SUGUVÕSA; kõige vähem materjali leidub klassis INIMENE ISE.

Mõisteklassis INIMENE KUI TERVIK hõlmavad enim fraseologisme üldmõisted PSÜÜHIKA ning ELUTÄHTSAD TOIMINGUD JA HARJUMUSED; järgnevad FÜSIOLOOGIA, KÕNEAKTID, FÜÜSIS, KEHAOSAD, AISTINGUD, MÕTTETEGEVUS, MORAAL, VANUS, SUGU, LIIGUTUSED ja INIMESE OLEMUS.

Kirjeldatud mõistekategooriat INIMENE katvate fraseologismide kujundsõna kuulub ontoloogiliselt suuremalt jaolt samasse mõistekategooriasse. Kuna inimliku argireaalsuse kujundamisel on kesksel kohal metafoorselt liigendatud mõistete süsteem, inimese mõtlemisprotsessid on suuresti metafoorsed ja oma metafoorset mõistesüsteemi kasutavad inimesed teadvustamatult (Lakoff \& Johnson 2011: $37 \mathrm{jj}$ ), siis leidub keeles lõputult mõistemetafoore, ent erinevate kujundsõnade rakendatus ning semantiline koormus on siiski väga erinev. 
Arvo Krikmann on juhtinud tähelepanu sellele, et folklooriüksuste kui tüüpide sageduslikul käitumisel on täielik analoogia Zipfi reegliga ${ }^{6}$ : mingis suuremas loomulikus allikmaterjalis on kõige rohkem väheproduktiivseid ning haruldasi tüpoloogilisi üksusi (s.t laule, jutte, vanasõnu jne), keskmine hulk keskmisi ja hästi vähe tohutu korduvusega üksusi (Krikmann 1997: 187-191). See reegel kehtib ka fraseologismide kujundsõna kohta (vt tabel 1).

FES-i 20749 fraseologismis on eristatud 3620 kujundsõna. Ülevaade kujundsõnade sagedusest - harvad, keskmise sagedusega ja väga sagedad - on esitatud tabelis 1 . Selles toodud arvandmetesse tuleks suhtuda teatud mööndusega, sest kujundsõna määramiseks puuduvad objektiivsed kriteeriumid. Subjektiivsuse moment ja sellest tulenev vigade võimalikkus ei muuda siiski põhimõttelist üldpilti.

Tabel 1. Kujundsõnade esinemissagedus fraseologismides.

\begin{tabular}{|l|l|l|}
\hline Sagedus & Kujundsõnade arv & Kujundsõnade osakaal (\%) \\
\hline 1 & 1566 & 43,25 \\
\hline 2 & 512 & 14,14 \\
\hline 3 & 323 & 8,92 \\
\hline$\ldots \ldots \ldots$ & & \\
\hline 4 & 142 & 3,9 \\
\hline 6 & 126 & 3,4 \\
\hline 7 & 85 & 2,3 \\
\hline 8 & 67 & 1,8 \\
\hline$\ldots \ldots \ldots$ & & \\
\hline 20 & 11 & 0,30 \\
\hline 21 & 12 & 0,33 \\
\hline 22 & 14 & 0,38 \\
\hline 23 & 12 & 0,33 \\
\hline$\ldots \ldots \ldots$ & & \\
\hline 108 & 3 & 0,082 \\
\hline 124 & 2 & 0,055 \\
\hline$\ldots \ldots \ldots$ & & \\
\hline 171 & 1 & 0,027 \\
\hline 196 & 1 & 0,027 \\
\hline 229 & 1 & 0,027 \\
\hline 273 & 1 & 0,027 \\
\hline
\end{tabular}

Nagu tabelist 1 nähtub, on kujundsõnade arv ja nende kasutussagedus pöördvõrdeline. Üle poole kujundsõnadest (2078) esinevad vaid ühes või kahes väljendis - neid fraseologisme võib nimetada haruldasteks. 
Suure semantilise koormusega kujundsõnad (vt tabel 2), mille esinemus haarab 50 ja rohkemat väljendit, moodustavad kujundsõnade koguhulgast (3620) väikese osa (61), ent neid sisaldavaid fraseologisme on palju (5456 üksust 20749 -st). Sagedusrea tipus (200-273 esinemust) on kujundsõnade ja fraseologismide koguarvu suhe vastavalt 6 ja 1546.

Tabel 2. Saja sagedasema kujundsõna ja fraseologismide suhe.

\begin{tabular}{|l|l|l|l|l|}
\hline Sagedus & $\begin{array}{l}\text { Kujund- } \\
\text { sõnade arv }\end{array}$ & $\begin{array}{l}\text { Kujundsõnade } \\
\text { osakaal (\%) }\end{array}$ & $\begin{array}{l}\text { Fraseo- } \\
\text { logismide arv }\end{array}$ & $\begin{array}{l}\text { Fraseologismide } \\
\text { osakaal (\%) }\end{array}$ \\
\hline $37-50$ & 40 & 1,10 & 528 & 2,54 \\
\hline $51-100$ & 33 & 0,91 & 1624 & 7,77 \\
\hline $101-150$ & 15 & 0,41 & 1259 & 6,06 \\
\hline $151-200$ & 6 & 0,16 & 1037 & 4,99 \\
\hline $200-250$ & 2 & 0,05 & 478 & 2,30 \\
\hline $251-273$ & 4 & 0,01 & 1068 & 5,14 \\
\hline Kokku & $\mathbf{1 0 0}$ & $\mathbf{2 , 7}$ & $\mathbf{5 9 8 4}$ & $\mathbf{2 8 , 8}$ \\
\hline
\end{tabular}

Nagu tabelist 2 näha, moodustavad sada sagedamat kujundsõna alla kolme protsendi kujundsõnade koguarvust (3600), kuid hõlmavad ligi kolmandiku (5984) fraseologismide koguarvust (20 749). Niisiis, fraseoloogias ilmneb jõuliselt vanasõnadest ja mõistatustest tuttav tendents: väike arv kujundsõnu - suur arv väljendeid, suur arv kujundsõnu - väike arv väljendeid.

\section{Kujundsõnade ontoloogiast}

100 kujundsõna sagedustabel 3 on koostatud selle järgi, kui mitme eri fraseologismi idiomaatilises keskmes mingi argireaalsuse mõiste osaleb. 100 enimkasutatud igapäevamõiste (kujundsõna) väikseim esinemus on 37 ja suurim 274 väljendit. Ontoloogilised sfäärid, milles realiseeruvad nii konventsionaalsed kui ka mittekonventsionaalsed ülekanded, on ootuspäraselt seotud inimliku ja zooloogilise sfääriga (loomad, linnud jt). Botaaniline sfäär, aeg, astronoomia, meteoroloogia ja üleloomulikud jõud on esindatud napilt. See kinnitab fraseologismide inimkeskset suunitlust.

Nagu näeme tabelist 3, jagunevad kujundsõnad väga ebaühtlaselt nii ontoloogiliste sfääride vahel kui ka sfääride allrühmades. Domineerib inimsfäär, sisuvalitsejateks on kehaosad ja koduloomad. Eeliskujundsõnade dominantsus on silmatorkav. Kui tuua sajast eelistatud kujundsõnast omakorda välja kümme kõige sagedamat ehk pingerea eesotsas olevat favoriitkujundsõna, siis avaneb pilt, mida illustreerib tabel 4 . 
Tabel 3. Saja kujundsõna ontoloogiline jaotus.

\begin{tabular}{|l|l|}
\hline Ontoloogiline sfäär & Kujundsõnade arv \\
\hline Inimsfäär & $\mathbf{6 9}$ \\
\hline kehaosad & 24 \\
\hline inimene kui selline & 6 \\
\hline mentaalne külg & 12 \\
\hline füsioloogilised eritised & 2 \\
\hline toit & 6 \\
\hline eluase & 2 \\
\hline esemed & 8 \\
\hline rõivad & 4 \\
\hline ained & 3 \\
\hline raha & 2 \\
\hline Zooloogia & $\mathbf{2 3}$ \\
\hline koduloomad & 10 \\
\hline metsloomad & 4 \\
\hline linnud & 4 \\
\hline putukad & 2 \\
\hline närilised jm & 3 \\
\hline Botaanika & $\mathbf{1}$ \\
\hline Aeg & $\mathbf{2}$ \\
\hline Astronoomia & $\mathbf{1}$ \\
\hline Meteoroloogia & $\mathbf{2}$ \\
\hline Üleloomulikud jõud & $\mathbf{2}$ \\
\hline Kokku & $\mathbf{1 0 0}$ \\
\hline & \\
\hline
\end{tabular}


Tabel 4. Kümme favoriitkujundsõna.

\begin{tabular}{|l|l|}
\hline Kujundsõna & $\begin{array}{l}\text { Fraseologismide arv } \\
\text { üldkogumis }(\mathbf{2 0} \text { 749) }\end{array}$ \\
\hline perse & 274 \\
\hline silm & 273 \\
\hline jalg & 261 \\
\hline koer & 260 \\
\hline pea & 249 \\
\hline suu & 229 \\
\hline käsi & 196 \\
\hline hunt & 176 \\
\hline süda & 172 \\
\hline siga & 171 \\
\hline &
\end{tabular}

Suurema osa eesti fraseoloogia kujundsõnade allikas on olnud eestlaste argieluga seonduv ja ajendatud inimese jaoks esmatähtsatest asjadest. Märkimisväärne hulk fraseologisme rajaneb igapäeva mõistealasid katvatel lekseemidel, mis märgivad inimese enda kõrval kehakatteid, toite, toiduaineid, mitmesuguseid saadusi ja vilju, olulisi tööriistu, anumaid ja köögitarbeid. Tähtsal kohal on ka eluspüsimiseks vajalik, näiteks päike (päev), muld, maa, tuli, vesi. Kuna uuritav materjal pärineb enamjaolt suulistest üleskirjutustest, siis on kujundsõnadeks loomulikult just suulise kõne valdkonda kuuluv leksika. See on üks põhjusi, miks eesti fraseoloogia on oma olemuselt vägagi argine ja rahvakeelne. Kujundsõna ontoloogiline alus on enamalt jaolt hästi mõistetav, mistõttu on metafoorne tulem suhteliselt lihtsalt äratuntav. Tehtud statistika (tabelid 3 ja 4) lubab väita, et eesti fraseoloogia keskmes on inimene. Ta on tihedalt seotud konkreetse elupraktikaga, ammutades sealt ka semantilise kujundi mõtestatavuse. Sellest aitab aru saada kognitiivne keelekäsitlus, mille järgi on inimlik mõistesüsteem struktureeritud ja määratletud suuresti metafoorselt, järelikult on metafoorselt struktureeritud ka mõistetele vastavad tegevused ja keeleüksused (vt nt Lakoff \& Johnson 2003: 3; Lakoff 2006: 186; Gibbs 2002: 262). On loomulik, et metafoorset keelt motiveerivad ühed ja samad inimlikus argitunnetuses olulised metafoorsed teadmised põhimõistetest, mida pidevalt kasutatakse igapäevastest kogemustest rääkides. Loomulik on ka see, et metafoorid ei pea alati olema konventsionaalsed. Põhilised mõistemetafoorid on mõisteliselt vältimatud ja seega konventsionaalsed, näiteks nagu SURM ON 
LAHKUMINE. Mõistetasandil tähendab konventsionaalsus seda, et mõistemetafoor on automaatne, sundimatu ja kehtib keelekogukonnas üldiselt kui mõtlemisviis. Keeletasandil on oluline, kui paljude argikeelendite aluseks mõistemetafoor on. Sugugi mitte kõik võimalikud metafoorsed väljendid ei ole mõisteliselt ainulaadsed. Kombineerides suhteliselt väikest hulka põhilisi mõistemetafoore võime saada tulemuseks keeleliste väljendite lõputud variandid (Lakoff \& Turner 1989: 51-56).

\section{Järeldusi ja kokkuvõtteid}

Fraseologismi sisuline terviklikkus prevaleerib vähemal või suuremal määral tema vormilise (grammatilise) liigenduse üle. Fraseologism koondab enda alla kõiki tema leksikaalse, morfosüntaktilise ja süntaktilise esinemise juhtumeid, on suhteliselt keeruline ja mitmekesine keeleainese kogum, millel on ligilähedane süntaktiline struktuur, enam-vähem sama tähendus ning sama mõisteline kujund. Mingi sageli esineva kujundi eri tahud võivad semantiliselt realiseeruda kas ligilähedase või erineva tähendusega väljendeis, mis kuuluvad kas samasse või erinevasse mõistevaldkonda (ei tee teist nägugi, teeb näo nagu .., mis näo teeb; enne kukub säde tulest, kui kopikas tema taskust, nagu tulesäde; must nagu süsi, nagu süte peal). Kujundituuma eristamise põhieesmärk on lahti kodeerida väljendi keskne kujund ning selle kaudu iseloomustada metafooride ülekandemehhanisme ja -suundi eesti keeles, leida üles ka väljendeis sadestunud meelekogemusi, mis on eestlastele tüüpilised.

Fraseologismi idiomaatiline kese, kujundituum on vastavuses meie tavapäraste mõistestruktuuridega, kujundi tekkemehhanismiga ja sellega, kuidas kujundi lähtealuseks olev mõiste on leksikaalselt ja grammatiliselt vormistatud ning kui suure hulga lekseemiga kaetud. Seda arvesse võttes saamegi sama kujundelemendi kaudu koondada erinevate keeletasandite (kirjakeel-kõnekeelmurre) erinevad leksikaalsed või erineva grammatilise struktuuriga teisendid. Näiteks väljendid kujundsõnaga latv: ladvast pehme, vares on latva tallanud. Sama mõistet katvaid väljendeid, mis on tähistatud erinevate emotiivsete või stiililt erinevate nii kirja- kui ka murdekeelsete sünonüümsete lekseemidega, on eesti vanemas fraseoloogias küllaga. Näiteks kujundsõna sõel alla koonduvad $e i$ seisa sõelas ega sarjas, tühjajutusari, saab sarjaga sauna viia 'palju lapsi', torgi nagu sarjapõhja, sõna sõglaga seljas, kuma kuud ega selita seula 'taevasõel'.

Eesti fraseoloogia kujundsõnad kuuluvad enamasti argimõistete valdkonda, nad märgivad meie esivanemate jaoks elutähtsaid asju, tegevusi ja enesestmõistetavalt iseennast. Kuna kujundi allikaiks on olnud eestlaste argieluga seonduv (kujundsõna esisada hõlmab suures osas inimsfääri ja ka zooloogilist 
valdkonda), siis rajaneb märkimisväärne hulk fraseologisme igapäeva mõistealasid katvatel lekseemidel, mis iseloomustavad meie argitegevusi, sotsiaalseid ja majanduslikke suhteid, väheke ka tõekspidamisi ja arusaamu maailma asjadest. Kujundsõnade hulgas on olulisel kohal ka see, mis on elus püsimiseks vajalik ja oluline, näiteks päike (päev), muld, maa, tuli, vesi. Uuritav materjal pärineb enamjaolt suulistest üleskirjutustest, seetõttu on kujundsõnadeks loomulikult just suulise kõne valdkonda kuuluv leksika. Neil põhjusil on eesti fraseoloogia oma olemuselt vägagi argine ja rahvakeelne.

Fraseoloogia kui sõnavaraosa ei ole jäik ega muutumatu. Konventsionaalsete mõistemetafooride laiendustena võivad tekkida uued keelendid, mis tõstavad esile seda, mis ei sobitu täpselt kokku meie tavapäraste mõistestruktuuridega.

\section{Kommentaarid}

1 Termineid fraseologism ja idioom kasutan artiklis sünonüümidena.

${ }^{2}$ http://www.kalale.ee/foorum/abiks-algajale/7C6A?page=0 - 03. september 2017.

3 www.via.ee/content/ - 03. september 2017.

4 www.tartu.postimees.ee/ - 03. september 2017.

5 Siin peame silmas tähendusüksusi, mida on kokku 26813

6 Kvantitatiivse e statistilise lingvistika rajaja George Kingsley Zipfi reegel: piisavalt pikas loomulikus tekstilõigus on tohutu hulk vähesagedasi, keskmine hulk keskmise korduvusega ja väga väike hulk tohutu korduvusega grammatiseerunud sõnu, vt Krikmann 1997 (http://haldjas.folklore.ee/ kriku/LEX/LOENG4.HTM\#N42 - 06. juuni 2017).

\section{Kirjandus}

Baranov, Anatoli \& Dobrovolski, Dmitri 1991 = Baranov, A. N. \& Dobrovol'skii, D. O. K universal'nomu opredeleniiu idiomy. Maket slovarnoi stat'i dlia avtomatizirovannogo tolkovo-ideograficheskogo slovaria russkikh frazeologizmov. Obraztsy slovarnykh statei. Moskva, lk 7-17.

Baranov, Anatoli \& Dobrovolski, Dmitri 1996 = Baranov, A. N. \& Dobrovol'skii, D. O. Idiomatichnost' i idiomy. Voprosy iazykoznaniia 5, lk 51-64.

Baranov, Anatoli \& Dobrovolski, Dmitri 2005 = Baranov, A. N. \& Dobrovol'skii, D. O. K poniatiiu idiomy. Leksikografiia i frazeologiia literaturnogo teksta. Breiteneder, Evelyn, Dobrovolskij, Dmitrij (toim). Dostojevskij in Focus: Textlexikographie und Phraseologie. Wien: Verlag der Österreichischen Akademie der Wissenschaften, lk 28-57.

Baranov, Anatoli \& Dobrovolski, Dmitri 2008 = Baranov, A. N. \& Dobrovol'skii, D. O. Aspekty teorii frazeologii. Moskva: Znak. 
Burger, Harald 2010 [2007]. Phraseologie. Eine Einführung am Beispiel des Deutschen. Grundlagen der Germanistik 36. Berlin: Erich Schmidt.

EKFA = Baran, Anneli \& Hussar, Anne \& Õim, Asta \& Õim, Katre (koost). Eesti kõnekäändude ja fraseologismide andmebaas. Tartu: Eesti Kirjandusmuuseum, 2005 (http://www.folklore.ee/justkui - 05. juuli 2017).

Espinal, Maria Teresa 2005. A conceptual dictionary of catalan idioms. International Journal of Lexicography 18 (4), lk 509-540 (doi: 10.1093/ij1/eci034).

EV 1980-1988 = Hussar, Anne \& Krikmann, Arvo \& Normann, Erna \& Pino, Veera \& Sarv, Ingrid \& Saukas, Rein (koost), Krikmann, Arvo \& Sarv, Ingrid (toim). Eesti vanasõnad. Monumenta Estoniae Antiquae I-V. Tallinn: Eesti Raamat (http://www. folklore.ee/rl/date/robotid/leht1.html - 05. juuli 2017).

Evans, Vivian 2007. A Glossary of Cognitive Linguistics. Edinburgh: Edinburgh University Press.

FES 2011 = Õim, Asta \& Õim, Katre (koost). Eesti fraseologismide elektrooniline alussõnastik. Tartu: Eesti Kirjandusmuuseum (http://www.folklore.ee/justkui/sonastik05. juuli 2017).

Gibbs, Raymond W. 2002 [1994]. The Poetics of Mind: Figurative Thought, Language, and Understanding. New York: Cambridge University Press.

Korhonen, Jarmo 2002. Typologien der Phraseologismen: Ein Überblick. Cruse, D. Alan \& Hundschnurser, Franz \& Job, Michael \& Lutzeier, Rolf Peter (toim). Lexikologie. Ein internationales Handbuch zur Natur und Struktur von Wörtern und Wortschätzen. Berlin \& New York: De Gruyter, lk 402-407.

Krikmann, Arvo 1997. Sissevaateid folkloori lühivormidesse I. Tartu: Tartu Ülikool (http://www.folklore.ee/ kriku/LEX/KATUS.HTM - 05. juuli 2017).

Krikmann, Arvo 1999. Eesti lühivormide allikaloost (http://www.folklore.ee/ kriku/ ALLIK/ - 05. juuli 2017).

Kuusi, Matti 1963. Sanaparsiston rakenneanalyysin terminologiaa. Virittäjä 4, lk 339_ 348.

Kövecses, Zoltan 2000. A Cognitive Linguistic View of Learning Idioms in an FLT Context. Essen: LAUD Linguistic Agency, University-GH Essen.

Lakoff, George \& Turner, Mark 1989. More than Cool Reason: A Field Guide to Poetic Metaphor. Chicago \& London: The University of Chicago Press (doi: 10.7208/ chicago/9780226470986.001.0001).

Lakoff, George \& Johnson, Mark 1999. Philosophy in the Flesh: The Embodied Mind and Its Challenge to Western Thought. New York: Basic Books.

Lakoff, George \& Johnson, Mark 2003 [1980]. Metaphors We Live By. Chicago \& London: The University of Chicago Press (doi: 10.7208/chicago/9780226470993.001.0001).

Lakoff, George 2006 [1993]. The Contemporary Theory of Metaphor. Geeraerts, Dirk (toim). Cognitive Linguistics: Basic Readings. Berlin \& New York: Mouton de Gruyter, lk 185-238. 
Lakoff, George \& Johnson, Mark 2011. Metafoorid, mille järgi me elame. Vainik, Ene (tlk). Tallinn: TLÜ Kirjastus.

Langlotz, Andreas 2006. Idiomatic Creativity: A cognitive-linguistic model of idiomrepresentation and idiom-variation in English. Amsterdam \& Philadelphia: John Benjamins Publishing Company (doi: 10.1075/hcp.17).

Õim, Asta 2008. Eesti kõnekä̈̈ndude ja fraseologismide mõistestik. Õim, Katre (toim). Tartu: Eesti Kirjandusmuuseum (http://www.folklore.ee/justkui/moiste.php - 05. juuli 2017).

Õim, Katre 1997. Eesti võrdluste struktuurist. Magistritöö. Tartu Ülikooli eesti keele õppetool.

Õim, Katre 2005. Fraseologism versus kõnekäänd. Erelt, Mati (toim). Emakeele Seltsi aastaraamat 50 (2004). Tallinn: Emakeele Selts, lk 129-142.

Õim, Katre 2009. Alternatiivseid mooduseid fraseoloogia esitamiseks sõnastikus. Eslon, Pille \& Õim, Katre (toim). Korpusuuringute metodoloogia ja märgendamise probleemid. Tallinn: Tallinna Ülikooli Kirjastus, lk 136-164.

Õim, Katre \& Õim, Asta 2011. Eesti fraseoloogia leksikograafiline areng. Keel ja Kirjandus 11, lk 842-862 (http://kjk.eki.ee/arhiiv/842-862.pdf - 04. juuli 2017).

\section{Summary}

\section{About figurative words in Estonian phraseology}

\section{Asta Õim}

linguist, Mother Tongue Society

asta.oim@gmail.com

Keywords: cognitive linguistics, Estonian language, figurative word, metaphor, phraseology

The material that the article is based on is comprised of phraseologisms (in all 20,749) included in the electronic base dictionary of Estonian idiomatic expressions. The theoretical basis is the idea that in case a linguistic unit - be it a word in its literal meaning, a phrase, or a sentence - is understood metaphorically, the metaphor is related to the literal meaning on the basis of a relationship or certain rules. This function is usually fulfilled by a trope.

The article focuses on the ontological nature of analysing figurative words in Estonian phraseologisms. For this purpose, the author presents the ontological characterisation of a hundred most frequent figurative words in Estonian phraseologisms, and, based on this, makes the following conclusions about Estonian phraseology: 1) The source of the image is related to Estonians' everyday life - the top hundred of figurative words cover the human sphere and zoology; 2) A remarkable number of phraseologisms are based on lexemes covering everyday domains, which characterise our beliefs, understandings, and 
everyday activities - the things needed for survival are essential; 3) Zipf's law applies there is a plethora of figurative words with extremely low frequency of occurrence (in one or two expressions), and a very small number of figurative words with extremely high frequency of occurrence (in a hundred or more expressions); 4) By its nature, Estonian phraseology is very commonplace and vernacular. One of the reasons for this is probably that the researched archival material mainly originates from oral speech notations. 